\title{
PERLINDUNGAN HUKUM BAGI PEKERJA RUMAH TANGGA DI BANDAR LAMPUNG
}

\author{
Muhtadi \\ Fakultas Hukum Universitas Lampung \\ email : muhtadi.1977@fh.unila.ac.id,muhtadi.hariman@gmail.com
}

\begin{abstract}
This research which is a grant of DIPA UNILA 2013 aims to describe the rights of domestic workers as well as models of legal protection for them in Bandar Lampung. By using a normative approach based on secondary data, it can be concluded that first, the rights of household workers are the same as in other sectors, the difference lies only in its job type, and secondly, a model of protection of household workers is done by means of preventive and repressive. Protection model preventively done by providing the local regulations that give legal certainty to the position of household workers, including the obligations of the agreement between workers and employers, while repressive carried out by means of law enforcement, both the penal or civil code. The penal code is carried out as a responsibility of the State to prosecute and/or punish the employer and / or the person in the house that his actions resulted in physical injury and/or psychological. While civil law is an effort to provide workers' rights which are not fulfilled in accordance with the employment agreement. It is recommended that in order to ensure legal certainty of the fulfillment of the rights of household workers in Bandar Lampung; it required legal norms that specifically governs the relationship of household workers and their employers in the form of local regulations.
\end{abstract}

Keywords: Legal Protection, Right and Household Workers.

\section{abstrak}

Penelitian ini yang merupakan hibah DIPA Unila 2013 bertujuan untuk menjabarkan hak-hak pekerja rumah tangga serta model perlindungan hukum bagi mereka di Bandar Lampung. Menggunakan pendekatan normatif berdasarkan data-data sekunder disimpulkan bahwa pertama hak-hak pekerja rumah tangga adalah sebagaimana hak pekerja di sektor lain, perbedaannya hanya terletak pada jenis pekerjaannya semata, dan kedua, model perlindungan pekerja rumah tanga dilakukan dengan cara preventif dan repressif. Secara preventif dilakukan dengan menyediakan perangkat hukum daerah (perda) yang memberikan jaminan kepastian hukum terhadap kedudukan pekerja rumah tangga, termasuk kewajiban adanya perjanjian/kesepakatan kerja antara pekerja dengan majikan, sedangkan 
secara repressif dilakukan dengan menggunakan sarana penegakan hukum, baik kode penal ataupun keperdataan. Kode penal dilakukan sebagai tanggung jawab negara untuk menuntut dan/atau menghukum majikan dan/atau orang yang ada di rumah tersebut yang perbuatannya mengakibatkan luka fisik dan/atau psikis. Sedangkan secara perdata merupakan upaya hukum untuk memberikan hak-hak pekerja yang tidak terpenuhi sesuai dengan perjanjian kerja. Untuk itu disarankan bahwa untuk menjamin kepastian hukum terpenuhinya hak-hak pekerja rumah tangga di Bandar Lampung diperlukan norma hukum yang secara spesifik mengatur hubungan pekerja rumah tangga dan majikannya dalam bentuk peraturan daerah.

Kata kunci : Perlindungan Hukum, Hak dan Pekerja Rumah Tangga

\section{A. Pendahuluan}

Organisasi Buruh Internasional (International Labour OrganisationILO) menyebutkan bahwa sampai tahun 2012 setidaknya terdapat 2,6 juta penduduk Indonesia yang bekerja sebagai pembantu rumah tangga (PRTdomestic helper), ${ }^{1}$ sebagian besar di antaranya adalah perempuan berpendidikan rendah, sedangkan kelompok pekerja laki-laki merupakan jumlah terkecil setelah perempuan dan anak-anak. Jumlah tersebut menurut ILO adalah tersebar di DKI Jakarta dengan jumlah terbesar 801.566; Jawa Timur: 402.762; Jawa Tengah: 399.159; Jawa Barat: 276.939; Banten: 100.352; Bali: 99.277; Sulawesi Selatan: 62.237; Lampung: 60.461; DIY: 39.914, serta propinsi lain seperi: Sumatera Utara, Riau, Sumatera Selatan, NTB, NTT, Kalimantan Barat, Kalimantan Timur, di mana jumlahnya tidak terpaut jauh. Akan tetapi, data jumlah PRT sebagaimana diungkapkan ILO tidak dimiliki oleh Kementerian Tenaga Kerja dan Transmigrasi, demikian pula ketiadaan data yang pasti di Dinas Tenaga Kerja Provinsi Lampung dan Kota Bandar Lampung.

Secara ekonomi, keberadaan PRT memberikan sumbangan yang signifikan terhadap kehidupan dan keuangan keluarga, bahkan berdampak positif bagi masyarakat di lingkungan tempat tinggal. Namun demikian, meskipun Pasal 27 ayat (2) Undang-Undang Dasar (UUD) Tahun 1945 menjamin setiap warga negara untuk mendapatkan pekerjaan dan penghidupan yang layak bagi kemanusiaan, demikian pula Pasal 28D ayat (2) memberikan jaminan orang untuk bekerja serta mendapat imbalan dan perlakuan yang adil dan layak dalam hubungan kerja, bahkan Pasal $28 \mathrm{H}$ ayat

\footnotetext{
${ }^{1}$ Kantor Perburuhan Internasional, Peraturan tentang Pekerja Rumah Tangga di Indonesia, Perundangan yang ada, standar internasional dan praktikterbaik, (Jakarta: ILO, 2006), hlm. 7.
} 
(1) menggariskan bahwa setiap orang berhak hidup sejahtera lahir dan batin, bertempat tinggal, dan mendapatkan lingkungan hidup baik dan sehat serta berhak memperoleh pelayanan kesehatan, realitanya, status PRT tidaklah sederajat dengan pekerja yang diatur dan diakui oleh Undang-Undang Nomor 13 Tahun 2003 tentang Ketenagakerjaan, ${ }^{2}$ bahkan temuan Jaringan Nasional Advokasi Pekerja Rumah Tangga (JALA PRT) sebagaimana disebutkan oleh Komisi Nasional Perempuan menunjukan adanya 726 kasus kekerasan dan penganiayaan berat yang dialami oleh pekerja rumah tangga, ${ }^{3}$ demikian pula pantauan terhadap media yang dilakukan Rieke Diah Pitaloka mengungkapkan 48 kasus kekerasan terhadap PRT sepanjang 2007-2012 yang terekspos ke publik. ${ }^{4}$

Selain terdapat berbagai kekerasan terhadap PRT, negara dan masyarakat masih memberikan stigma dan perlakuan diskriminatif yang ditunjukan antara lain dengan cara: 1) anggapan kuat bahwa pekerjaan rumah tangga tidak/rendah keterampilan, yang mengakibatkan pengabaian hak-hak mereka; 2) anggapan bahwa pekerjaan rumah tangga bersifat domestik dan informal, sehingga tidak perlu diatur dengan perangkat hukum yang menjamin hak dan perlindungan mereka selayaknya pekerja lain di sektor formal; dan 3) pekerjaan rumah tangga belum diakui sebagai pekerjaan, sehingga perlindungan sangat bertumpu pada kebaikan hati majikan. Hal ini terkesan mengukuhkan perbudakan modern dan menjauhkan hak dasar pekerja rumah tangga akan perlindungan dan pemenuhan hak. ${ }^{5}$

Sebagai pekerja, PRT melakukan pekerjaan penatalaksanaan terhadap seluruh kepentingan rumah tangga majikan (pemberi pekerjaan) dengan jam kerja panjang, bahkan lebih panjang dari aktifitas pemilik rumah, melakukan berbagai pekerjaan dari mencuci dan setrika pakaian, memasak, mengasuh anak, dan bahkan mengurus kebun, namun jaminan kepastian dan perlindungan hukum untuk tidak mengalami berbagai kekerasan ataupun mempunyai hak sesuai dengan jumlah jam kerja tidaklah selalu diperoleh secara layak, bahkan gaji atas pekerjaan lebih banyak diberikan bukan atas keterampilan ataupun pengalaman dan masa kerja, melainkan atas belas kasihan majikan.

Berbagai kekerasan dan diskriminasi perlakuan terhadap PRT salah satunya disebabkan oleh tidak adanya peraturan perundang-undangan yang

\footnotetext{
${ }^{2}$ Lembaran Negara Republik Indonesia (LNRI) Tahun 2003 Nomor 39, Tambahan Lembaran Negara Republik Indonesia (TLNRI) Nomor 4279.

3 http://www.komnasperempuan.or.id/2011/03/dpr-harus-segera-membahas-danmengesahkan-ruu-perlindungan-pekerja-rumah-tangga/, akses terakhir 10 Maret 2013

$4 \mathrm{http} / / / \mathrm{www}$.riekediahpitaloka.com/release/201202/15-februari-hari-prt-indonesia-sby-manajanjimu/, akses terakhir 10 Maret 2013.

${ }^{5}$ Komnas Perempuan, Op.Cit.
} 
melegitimasi eksistensi PRT sebagai pekerja yang tunduk pada hukum ataupun perjanjian kerja antara pekerja dan majikan, bukan saja norma hukum setingkat undang-undang bahkan tidak tersedianya peraturan daerah yang seharusnya menjadi payung hukum perlindungan PRT oleh pemerintah daerah ikut memberikan dampak negatif. Untuk itu, menjadi penting dilakukan pemetaan persoalan PRT di Kota Bandar Lampung yang pada akhirnya melahirkan model kebijakan perlindungan bagi PRT.

Persoalanya bagaimanakah model perlindungan hukum yang dapat diberikan kepada Pembantu Rumah Tangga di Kota Bandar Lampung?

\section{B. Pembahasan}

\section{Pengakuan, Pengaturan dan Perlindungan Hak Konstitusional Pekerja}

UUD Tahun 1945 sebagai hukum dasar negara memberikan jaminan bahwa setiap warga negara untuk mendapatkan pekerjaan dan penghidupan yang layak bagi kemanusiaan sebagaimana dimaksud Pasal 27 ayat (2), demikian pula Pasal 28D ayat (2) mengakui hak setiap orang untuk bekerja serta mendapat imbalan dan perlakuan yang adil dan layak dalam hubungan kerja, bahkan Pasal 28H ayat (1) menggariskan bahwa setiap orang berhak hidup sejahtera lahir dan batin, bertempat tinggal, dan mendapatkan lingkungan hidup baik dan sehat serta berhak memperoleh pelayanan kesehatan, lebih dari itu, para pendiri negara mengkontruksikan tujuan berbangsa dan bernegara adalah melindungi segenap tumpah darah Indonesia dan memajukan kesejahteraan umum yang di dasarkan atas keadilan sosial. Guna mewujudkan kehendak tersebut, Pasal 28I ayat (5) UUD Tahun 1945 menyaratkan bahwa untuk menegakan dan melindungi hak asasi manusia sesuai dengan prinsip negara hukum yang demokratis, maka pelaksanaan hak asasi manusia dijamin, diatur, dan dituangkan dalam peraturan perundangan-undangan. Peraturan dimaksud salah satunya adalah Undang-Undang Nomor 39 Tahun 1999 tentang Hak Asasi Manusia (UU HAM). ${ }^{6}$

Sebagai umbrella act, UU HAM secara spesifik dalam bagian ketujuh tentang hak atas kesejahteraan, khususnya Pasal 38 memberikan pengakuan dan pengaturan bahwa :

a. setiap warga negara, sesuai dengan bakat, kecakapan, dan kemampuan, berhak atas pekerjaan yang layak;

b. setiap orang berhak dengan bebas memilih pekerjaan yang disukainya dan berhak pula atas syarat-syarat ketenagakerjaan yang adil;

\footnotetext{
${ }^{6}$ LNRI Tahun 1999 Nomor 165, TLNRI Nomor 3886.
} 
c. setiap orang, baik pria maupun wanita yang melakukan pekerjaan yang sama, sebanding, setara atau serupa, berhak atas upah serta syarat-syarat perjanjian kerja yang sama;

d. setiap orang, baik pria maupun wanita, dalam melakukan pekerjaan yang sepadan dengan martabat kemanusiaannya berhak atas upah yang adil sesuai dengan prestasinya dan dapat menjamin kelangsungan kehidupan keluarganya.

Perlakuan khusus terhadap kelompok rentan sebagaimana dimaksud Pasal 41 ayat (2) yang menyebutkan bahwa setiap penyandang cacat, orang yang berusia lanjut, wanita hamil, dan anak-anak, berhak memperoleh kemudahan dan perlakuan khusus.

Pada tingkat internasional, tanggal 16 Juni 2011, sesi ke-100 Sidang ILO dengan tema "Kerja Layak" mengadopsi Konvensi ILO No. 189 Mengenai Kerja Layak Pekerja Rumah Tangga, yang di dalam konvensi tersebut diatur antara lain:

a. pengakuan PRT sebagai pekerja yang mempunyai hak harus dilindungi dan dihormati selama bekerja; dan

b. standar perlakuan yang bertujuan untuk melindungi PRT. Di antaranya perlindungan berdasar prinsip hak asasi manusia, di antaranya penghapusan diskriminasi bagi perempuan, perlindungan hak anak, perwujudan hak sipil politik dan ekonomi, sosial dan budaya, perlindungan dari pelanggaran hak dan kesewenangan, penghapusan kerja paksa dan hak lainnya seperti jam kerja, waktu libur, waktu istirahat, jaminan sosial, pendidikan dan pelatihan, dll.

Akan tetapi, Nomenklatur (Istilah) pekerja dari frase "pekerja rumah tangga" dalam Kamus Besar Bahasa Indonesia (KBBI) tidaklah diartikan sebagai bagian dari pengertian pekerja, melainkan menggunakan nomenklatur khusus, yaitu Pembantu Rumah Tangga. ${ }^{7}$ Pekerja diartikan sebagai: 1) orang yang bekerja; 2) orang yang menerima upah atas hasil kerjanya; buruh; karyawan. ${ }^{8}$ Sedangkan pembantu rumah tangga diartikan sebagai 1) orang (alat dsb) yang membantu; penolong; 2) orang upahan, pekerjaannya (membantu) mengurus pekerjaan rumah tangga (memasak, mencuci, menyapu, dsb). ${ }^{9}$ Bertalian dengan makna pekerja tersebut, ditemukan padanannya, yaitu tenaga kerja, yang berarti 1) orang yang bekerja atau mengerjakan sesuatu; pekerja; pegawai; dsb, 2) orang yang mampu melakukan pekerjaan, baik di dalam maupun di luar hubungan kerja, ${ }^{10}$ dan secara mutatis mutandis, Pasal 1 angka 2 UU Ketenagakerjaan

\footnotetext{
${ }^{7}$ Tim Penyusun, Kamus Besar Bahasa Indonesia, Departemen Pendidikan dan Kebudayaan, Jakarta, 2002, hlm. 105.

${ }^{8}$ Ibid., hlm. 554.

${ }^{9}$ Ibid., hlm. 105.

${ }^{10}$ Ibid., hlm. 1171.
} 
memberikan batasan arti pekerja sebagai setiap orang yang mampu melakukan pekerjaan guna menghasilkan barang dan/atau jasa baik untuk memenuhi kebutuhan sendiri maupun untuk masyarakat. Sedangkan Pasal 1 angka 3 UU Ketenagakerjaan menyebutkan pekerja/buruh adalah setiap orang yang bekerja dengan menerima upah atau imbalan dalam bentuk lain. Dengan demikian, meskipun secara gramatikal Pembantu Rumah Tangga dipisahkan pengertiannya dari istilah pekerja pada umumnya, tetapi dikategorikan sebagai bagian maksud pengertian pekerja tersebut.

Kontruksi pengakuan hak serta kewajiban pekerja dalam UU Ketenagakerjaan apabila disandingkan dengan jenis dan waktu pelaksanaan pekerjaan PRT menunjukan adanya ketidaksesuaian pengaturan norma tersebut dengan praktek perlakuan masyarakat atau pengguna jasa terhadap PRT. Perlakuan tidak patut tersebut antara lain PRT tidak mempunyai uang lembur atau kelebihan jam kerja normatif, ${ }^{11} 7$ jam satu hari dengan masa kerja 6 hari satu minggu atau 8 jam per hari untuk lima hari kerja, ${ }^{12}$ cuti kerja tidak jelas, ${ }^{13}$ bahkan besaran upah yang tidak tunduk pada standar pengupahan yang berlaku di provinsi atau kabupaten/kota. ${ }^{14}$ Disamping perlakuan hukum yang tidak sesuai dengan kaidah normatif tersebut, temuan berbagai penelitian sebelumnya yang dilakukan oleh Komnas Perempuan, JALA PRT ataupun ILO menunjukan berbagai kekerasan yang menimpa PRT, khususnya perempuan dan anak. Jenis kekerasan tersebut antara lain tidak diberi makan, dikurung dalam kamar mandi, penyiksaan, larangan menjalankan ibadah, pemaksaan memakan makanan yang tidak halal, pelecehan seksual sampai pada tingkat pemerekosaan, dan bahkan penyiksaan yang berujung pada kematian.

\section{Hak-Hak Pekerja Rumah Tangga}

Pasal 1 angka 2 UU Ketenagakerjaan memberikan batasan arti pekerja sebagai setiap orang yang mampu melakukan pekerjaan guna menghasilkan barang dan/atau jasa baik untuk memenuhi kebutuhan sendiri maupun untuk masyarakat. Sedangkan Pasal 1 angka 3 UU Ketenagakerjaan menyebutkan pekerja/buruh adalah setiap orang yang bekerja dengan menerima upah atau imbalan dalam bentuk lain. Dengan demikian, meskipun secara gramatikal Pembantu Rumah Tangga dipisahkan pengertiannya dari istilah pekerja pada umumnya, tetapi dikategorikan sebagai bagian maksud pengertian pekerja tersebut. Karenanya hak-hak pekerja rumah tangga sejatinya adalah juga hak-hak yang diperoleh pekerja sebagaimana dimaksud UU Ketenagakerjaan

\footnotetext{
${ }^{11}$ Lihat Pasal 78 UU Ketenagakerjaan.

${ }^{12}$ Lihat Pasal 77 UU Ketenagakerjaan.

${ }^{13}$ Lihat Pasal 79 UU Ketenagakerjaan.

${ }^{14}$ Lihat Pasal 88 UU Ketenagakerjaan.
} 
yang bermuara pada hak-hak konstitusional pekerja yang diatur UUD Tahun 1945, sehingga setiap pelanggaran terhadap hak pekerja rumah tangga dapat dikategorikan sebagai perlawanan terhadap konstitusi.

Secara exvressi verbis (tersurat), UUD Tahun 1945 menjamin bahwa setiap warga negara untuk mendapatkan pekerjaan dan penghidupan yang layak bagi kemanusiaan sebagaimana dimaksud Pasal 27 ayat (2), demikian pula Pasal 28D ayat (2) mengkui hak setiap orang untuk bekerja serta mendapat imbalan dan perlakuan yang adil dan layak dalam hubungan kerja, bahkan Pasal 28H ayat (1) menggariskan bahwa setiap orang berhak hidup sejahtera lahir dan batin, bertempat tinggal, dan mendapatkan lingkungan hidup baik dan sehat serta berhak memperoleh pelayanan kesehatan, lebih dari itu, para pendiri negara mengkontruksikan tujuan berbangsa dan bernegara adalah melindungi segenap tumpah darah Indonesia dan memajukan kesejahteraan umum yang di dasarkan atas keadilan sosial. Guna mewujudkan kehendak tersebut, Pasal 28I ayat (5) UUD Tahun 1945 menyaratkan bahwa untuk menegakan dan melindungi hak asasi manusia sesuai dengan prinsip negara hukum yang demokratis, maka pelaksanaan hak asasi manusia dijamin, diatur, dan dituangkan dalam peraturan perundang-undangan.

Pengaturan sebagaimana dimaksud Pasal 28I tersebut adalah UU HAM, yang secara spesifik dalam bagian ketujuh tentang hak atas kesejahteraan, khususnya Pasal 38 memberikan pengakuan dan pengaturan bahwa :

(1) Setiap warga negara, sesuai dengan bakat, kecakapan, dan kemampuan, berhak atas pekerjaan yang layak.

(2) Setiap orang berhak dengan bebas memilih pekerjaan yang disukainya dan berhak pula atas syarat-syarat ketenagakerjaan yang adil.

(3) Setiap orang, baik pria maupun wanita yang melakukan pekerjaan yang sama, sebanding, setara atau serupa, berhak atas upah serta syarat-syarat perjanjian kerja yang sama.

(4) Setiap orang, baik pria maupun wanita, dalam melakukan pekerjaan yang sepadan dengan martabat kemanusiaannya berhak atas upah yang adil sesuai dengan prestasinya dan dapat menjamin kelangsungan kehidupan keluarganya.

Pada 16 Juni 2011, sesi ke-100 Sidang ILO dengan tema "Kerja Layak" mengadopsi Konvensi ILO No. 189 Mengenai Kerja Layak Pekerja Rumah Tangga, yang di dalam konvensi tersebut diatur antara lain:

a. pengakuan PRT sebagai pekerja yang mempunyai hak harus dilindungi dan dihormati selama bekerja; dan

b. standar perlakuan yang bertujuan untuk melindungi PRT. Di antaranya perlindungan berdasar prinsip hak asasi manusia, di antaranya penghapusan diskriminasi bagi perempuan, perlindungan hak anak, 
perwujudan hak sipil politik dan ekonomi, sosial dan budaya, perlindungan dari pelanggaran hak dan kesewenangan, penghapusan kerja paksa dan hak lainnya seperti jam kerja, waktu libur, waktu istirahat, jaminan sosial, pendidikan dan pelatihan, dll.

Kontekstualisasi pengakuan terhadap hak-hak pekerja sebagaimana dimaksud konstitusi adalah diatur dalam UU Ketenagakerjaan. Namun demikian hak-hak pekerja rumah tangga.

\section{Model Perlindungan Pekerja Rumah Tangga di Bandar Lampung a. Perlindungan preventif}

Secara yuridis, PRT memang bebas, sebab negara kita melarang perbudakan dan perhambaan. Tapi dari kacamata sosiologis, yang terjadi justru sebaliknya, PRT tidak bebas. Sebagai orang yang memiliki keterbatasan bekal hidup selain tenaganya, PRT terpaksa bekerja pada orang lain dalam hal ini pemberi kerja yang memiliki otoritas menentukan syaratsyarat kerja. Relatif rendahnya tingkat pendidikan menutup kemampuan PRT mengekspos hak-haknya serta tak dapat merespon berbagai informasi yang dapat meningkatkan taraf hidupnya. Selama aturan main hubungan PRT dengan pemberi kerja diserahkan kepada kedua belah pihak, maka sukar dicapai suatu keseimbangan kepentingan yang mengedepankan nilainilai keadilan. Sampai saat ini belum satupun lembaga atau yayasan penyalur PRT, memelopori penggarapan nasib para PRT dari sisi perlindungan hukum dan pemberdayaan. Dalam dunia akademik pun sangat langka menemukan hasil penelitian yang secara tematis mengangkat persoalan PRT. Bahkan pemerintahpun tidak pernah menggagas kampanye untuk membangkitkan kepedulian terhadap PRT. Namun demikian terdapat beberapa hal yang barangkali patut diagendakan sebagai upaya berarti untuk memberikan perlindungan terhadap PRT antara lain :

1) advocacy, mengangkat ke permukaan kasus-kasus PRT agar memperoleh respon banyak pihak guna menjadi agenda dalam upaya perubahan ke arah yang lebih baik;

2) paralegal, sebagai bentuk penyadaran hukum dan aksi untuk melindungi diri PRT dari berbagai tekanan pemberi kerja. Perlu dibentuk pusat-pusat pelayanan sebagai bagian dari bentuk pengorganisasian, termasuk upaya untuk menggagas terbentuknya organisasi serikat pekerja khusus PRT. Pembentukan serikat pekerja dalam hal ini tidak berarti menciptakan kaidah dari tidak ada menjadi ada tetapi juga menempatkan komunitas PRT secara afiliatif organisatoris terhadap organisasi Serikat Pekerja yang sudah mapan; 
3) Law Reform (Reformasi Hukum) ${ }^{15}$, pembaruan hukum yang diformulasikan dalam berbagai kebijakan berbasis keberpihakan kepada PRT dalam kerangka perlindungan dan pemberdayaan serta pembinaan hubungan kerja. Law Reform ini dapat dilakukan dilakukan dengan menyediakan perangkat hukum daerah (perda) sebagai hasil evalusi dan pengkajian atas realitas hubungan PRTpemberi kerja berikut problem yang menyertainya. Dengan adanya perangkat hukum tersebut, merupakan momentum bagi pemerintah di bidang hukum untuk segera melakukan perlindungan secara mendasar sebagai wujud komitmen dan konsistensinya, pemerintah segera membentuk perundang-undangan (law making) yang khusus memberikan perlindungan terhadap PRT.Secara umum upaya ini dapat dimaknai sebagai melindungi atau memberikan pertolongan dalam bidang hukum upaya yang ditujukan untuk memberikan rasa aman diberikan terhadap subjek hukum dalam bentuk perangkat hukum baik yang bersifat preventif maupun yang bersifat represif. Perda harus memperhatikan persoalan-persoalan di bawah ini:

a) peraturan Daerah harus memperhatikan undang-undang dan peraturan lainnya yang berkaitan. Misalnya, perlindungan bagi PRT harus bisa menindaki pelaku kekerasan yang menghindari sanksi hukum. Oleh karena itu, pelaksana undang-undang dan sidang pidana harus siap untuk menegakan hukum tanpa diskriminasi;

b) organisasi masyarakat sipil seperti akademisi dan LSM, agen tenaga kerja, dan pekerja rumah tangga itu sendiri harus turut dilibatkan dalam merancang peraturan daerah atau peraturan-peraturan lainnya;

c) Mempersiapkan petunjuk pelaksanaan peraturan tentang bagaimana menerapkan peraturan-peraturan itu. Petunjuk Pelaksanaan Peraturan ini harus jelas dan sejalan dengan peraturan lainnya dan mendorong koordinasi dengan pelaksana hukum. Jika tidak demikian, maka undang-undang tersebut tidak dapat diimplementasikan;

d) mensosialisasikan dan mengkomunikasikan segala informasi yang berkaitan dengan undang-undang untuk melindungi PRT kepada semua pihak yang terlibat di dalam urusan ini, seperti pemberi kerja/majikan, agen tenaga kerja, dan pekerja rumah tangga. Tujuannya adalah untuk mendapatkan dukungan dan komitmen dari para penentu kebijakan untuk menjalankan undang-undang tersebut.

e) Membuat undang-undang yang sistematis dan menggunakan istilahistilah hukum yang sederhana agar dapat mempermudah para penentu kebijakan dalam melaksanakannya. Bahasa yang digunakan di dalam

15 Munir Fuady, Pengorganisasian Buruh Perempuan, Makalah, dipresentasikan di LBH Surabaya, 1998. Makalah, dipresentasikan di LBH Surabaya. 1998. 
undang-undang itu harus jelas agar dapat terhindar dari kesalahpahaman yang dapat memberi peluang penyalahgunaannya. Jika penyalahgunaan hukum ini terjadi, PRT tidak akan dapat perlindungan karena mereka tidak memiliki kekuatan tawar-menawar untuk merundingkan kepentingan mereka secara hukum.

Selain daripada itu untuk memberikan suatu pengamanan terhadap para PRT dalam bentuk dengan fisible dan berkekuatan hukum diperlukan pula suatu penjanjian kerja dalam bentuk tertulis antara majikan dengan pekerja guna menimbulkan semua hubungan hukum antara dua orang atau lebih yang lazim disebut dengan perikatan. Sebagaimana yang dikemukakan oleh R. Subekti:

"Hukum perjanjian memberikan kebebasan yang seluas-luasnya kepada masyarakat untuk mengadakan perjanjian yang berisi apa saja, asalkantidak melanggar ketertiban umum dan kesusilaan". ${ }^{16}$ Dalam hal ini antara pekerja dan majikan diperbolehkan mengatur sendiri kepentingan mereka dalam perjanjian yang mereka adakan. Guna mewujudkan suatu perjanjian yang telah disepakati bersama, para pihak yang terikat dalam perjanjian harus melaksanakan isi perjanjian sebagaimana mestinya. Dengan dilaksanakannya prestasi dalam perjanjian maka apa yang diharapkan sebagai maksud dan tujuan diadakannya perjanjian akan tercipta dengan baik tanpa ada pihak yang dirugikan yang dapat menuntut atas kerugian yang dideritanya.

Demikian juga dalam bidang pekerjaan, orang melakukan perjanjian kerjasehingga menimbulkan perikatan. Setiap hubungan kerja yang tercipta, baik formal maupun informal, pada dasarnya selalu didahului dengan adanya perjanjian kerja. Untuk pekerjaan informal, perjanjian kerja antara pemberi pekerjaan dengan penerima pekerjaan biasanya dilakukan secara lisan sedangkan pekerjaan-pekerjaan yang formal, seperti di pabrik atau perusahaan, perjanjian kerja pada umumnya dibuat secara tertulis. Pada dasarnya baik tertulis maupun tidak, perjanjian kerja tersebut sama-sama mempunyai kekuatan yang mengikat kedua belah pihak.

\section{b. Perlindungan Repressif}

Dalam hal ini perlindungan hukum terhadap Pekerja Rumah Tangga bukan hanya dilakukan secara preventif namun harus juga secara repressif, karena tidak cukup dengan adanya instrumen hukum sebagai suatu kebijakan semata. Pada prinsipnya hukum sebagai suatu bentuk kelembagaan sosial yang mewadahi kebijakan penyelenggaraan negara menjangkau semua bidang dan aspek kehidupan manusia dan mengintegrasikannya ke dalam suatu sistem sosial yang harmonis dan fungsional. Secara konseptual,

\footnotetext{
${ }^{16}$ R. Subekti, Hukum Perjanji an Cetakan keduabelas , (Jakarta: PT. Intermasa, 1987), hlm. 9
} 
kebijakan hukum merupakan bagian tidak terpisahkan (integral) dari kebijakan sosial; artinya kebijakan sosial mencakup di dalamnya kebijakan hukum, yang selengkapnya disebut kebijakan penegakan hukum (law enforcement policy). Dalam lingkup kebijakan (penegakan) hukum ini hukum administrasi dan hukum keperdataan menempati kedudukan yang sama dengan hukum pidana sebagai sarana penanggulangan kejahatan. Ini berarti, kebijakan perundang-undangan serta penegakan hukum merupakan bagian dari kebijakan sosial.

Kebijakan sosial tersebut kemudian diimplementasikan di dalam bentuk berbagai kebijakan lanjutan sebagai upaya untuk merealisasikan apa yang telah ditetapkan sebagai kebijakan sosial. Salah satu bentuk sarana pengejawantahan kebijakan sosial tadi adalah kebijakan hukum atau kebijakan penegakan hukum. Kebijakan pembangunan merupakan bentuk sarana realisasi dari kebijakan sosial nasional yang meliputi kebijakan hukum, maka kebijakan pembangunan nasional di bidang hukum berfungsi sebagai pendukung bagi terwujudnya tujuan pembangunan nasional secara keseluruhan yang juga berarti terwujudnya tujuan nasional kehidupan berbangsa dan bernegara. Hal ini juga berarti bahwa pelaksanaan pembangunan nasional di segala bidang kehidupan, inklusif pembangunan di bidang hukum, sesungguhnya merupakan proses perwujudan kebijakan sosial nasional.

Dalam teori Sibernetika dari Talcott Parson ${ }^{17}$, hukum digambarkan sebagai subsistem sosial yang berfungsi mengintegrasikan semua subsistem sosial yang ada, sehingga memungkinkan semua bagian dari suatu sistem sosial itu dapat berfungsi/bekerja secara optimal, efektif, dan efisien. Berdasarkan kerangka berpikir ini dapat pula diartikan bahwa manakala hukum tidak dapat menjalankan fungsi dengan baik sebagai sarana pengintegrasi, maka kehidupan sosial akan mengalami gangguan atau disintegrasi.

Penegakan hukum merupakan suatu proses untuk mewujudkan keinginan-keinginan hukum menjadi kenyataan. Keinginan-keinginan hukum ini adalah pikiran-pikiran badan pembentuk undang-undang yang dirumuskan dalam peraturan-peraturan hukum itu. Perumusan pikiran pembuat hukum yang dituangkan dalam peraturan hukum, turut menentukan bagaimana penegakan hukum itu dijalankan. Dengan demikian pada gilirannya, proses penegakan hukum itu memuncak pada pelaksanaannya oleh para pejabat penegak hukum itu sendiri. Dari keadaan ini, dengan nada ekstrim dapat dikatakan bahwa keberhasilan ataupun kegagalan para

\footnotetext{
${ }^{17}$ Jurnal ilmu sosial dan ilmu politik, Fakultas Sosial dan Fakultas Politik, Universitas Riau, 1994.
} 
penegak hukum dalam melaksanakan tugasnya sebetulnya sudah dimulai sejak peraturan hukum yang harus dijalankan itu dibuat.

Proses penegakan hukum dipengaruhi oleh lima faktor. Pertama, faktor hukum atau peraturan perundang-undangan. Kedua, faktor aparat penegak hukumnya, yakni pihak-pihak yang terlibat dalam proses pembuatan dan penerapan hukumnya, yang berkaitan dengan masalah mentalitas. Ketiga, faktor sarana atau fasilitas yang mendukung proses penegakan hukum. Keempat, faktor masyarakat, yakni lingkungan sosial di mana hukum tersebut berlaku atau diterapkan, berhubungan dengan kesadaran dan kepatuhan hukum yang merefleksi dalam perilaku masyarakat. Kelima, faktor kebudayaan, yakni hasil karya, cipta, dan rasa yang di dasarkan pada karsa manusia di dalam pergaulan hidup.

Karakter hukum positif dalam wujudnya sebagai peraturan perundangundangan, di samping ditentukan oleh konfigurasi politik momentum pembuatannya, juga berkaitan erat dengan komitmen moral serta profesional dari para anggota legislatif itu sendiri. Semangat hukum (spirit of law) berkaitan erat dengan visi pembentuk undang-undang, maka dalam konteks membangun hukum yang demokratis, peran dan visi pembentuk undangundang sedemikian penting. Pembentuk undang-undang tidak semata-mata berkewajiban untuk memberikan sumbangan terhadap pembentukan perubahan masyarakat itu sendiri. Dengan demikian, pembentuk undangundang, tidak lagi semata-mata mengikuti perubahan masyarakat, akan tetapi justru mendahului perubahan masyarakat itu. Dalam konteks ini, pembentuk undang-undang berkewajiban mengkreasi kebijakan dalam wujud perundang-undangan yang responsif terhadap tuntutan terwujudnya keadilan gender dalam kehidupan masyarakat.

Selain itu dibidang keperdataan menyangkut perjanjian kontrak guna melindungi para PRT, antara pengusaha dengan pekerja/buruh berdasarkan perjanjian kerja, yang mempunyai unsur pekerjaan,upah, dan perintah. Hubungan kerja terjadi setelah adanya perjanjian kerja antara buruh dan majikan, yaitu suatu perjanjian di mana pihak kesatu, buruh, mengikatkan diri untuk bekerja dengan menerima upah pada pihak lainnya, majikan, yang mengikatkan diri untuk mempekerjakan buruh itu dengan membayar upah. "Pada pihak lainnya" mengandung arti bahwa pihak buruh dalam melakukan pekerjaan itu berada di bawah pimpinan pihak majikan. Agar kedua belah pihak dapat melaksanakan hubungan kerja dengan baik, tanpa adanya tindakan sewenang-wenang dari salah satu pihak maka diperlukan adanya campur tangan dari pemerintah dalam bentuk peraturan-perundangundangan.

Adanya peraturan perundang-undangan ditujukan untuk pengendalian. Baik pemberi pekerja maupun yang diberi pekerjaan, masing-masing harus terkendali atau masing-masing harus menundukan diri pada segala ketentuan 
dan peraturan yang berlaku, harus bertanggungjawab dalam melaksanakan kegiatan masing-masing sesuai dengan tugas dan wewenangnya, hingga keserasian dan keselarasan akan selalu terwujud.

\section{Penutup}

Berdasarkan berbagai temuan tersebut, dapat disimpulkan bahwa, pertama, hak-hak pekerja rumah tangga adalah sebagaimana hak pekerja di sektor lain, perbedaannya hanya terletak pada jenis pekerjaannya semata, dan kedua, model perlindungan pekerja rumah tangga dilakukan dengan cara preventif dan repressif. Secara preventif dilakukan dengan menyediakan perangkat hukum daerah (perda) yang memberikan jaminan kepastian hukum terhadap kedudukan pekerja rumah tangga, termasuk kewajiban adanya perjanjian/kesepakatan kerja antara pekerja dengan majikan, sedangkan secara repressif dilakukan dengan menggunakan sarana

penegakan hukum, baik kode penal ataupun keperdataan. Kode penal dilakukan sebagai tanggung jawab negara untuk menuntut dan/atau menghukum majikan dan/atau orang yang ada di rumah tersebut yang perbuatannya mengakibatkan luka fisik dan/atau psikis. Sedangkan secara perdata merupakan upaya hukum untuk memberikan hak-hak pekerja yang tidak terpenuhi sesuai dengan perjanjian kerja.

Guna mencapai maksud sebagaimana simpulan penelitian tersebut, disarankan bahwa untuk menjamin kepastian hukum terpenuhinya hak-hak pekerja rumah tangga di Bandar Lampung diperlukan norma hukum yang secara spesifik mengatur hubungan pekerja rumah tangga dan majikannya dalam bentuk peraturan daerah.

\section{Daftar Pustaka}

\section{A. Buku}

Abikusumo, R,M., 2010. Lahirnya UUD Tahun 1945, Jakarta: FH UI. Asshiddiqie, Jimly, 2008. Pokok-pokok Hukum Tata Negara Indonesia Pasca Reformasi, Jakarta: BIP.

Baehr, Peter R, 1998, Hak-Hak Asasi Manusia dan Politik Luar Negeri, Jakarta: Yayasan OborIndonesia.

Bruggink, J.J.H, 1999 Rechtsreflecties, Grondbegrippenuit de Rechtstheorie (Refleksi tentang Hukum, alih bahasa Arief Sidharta, Bandung: PT, Citra Aditya Bhakti.

Budiardjo, Miriam, 2010. Dasar-Dasar Ilmu Politik, Jakarta: PT, Gramedia. Fajar, Mukti dan Yulianto Achmad, 2007. Dualisme Penelitian Hukum, Yogyakarta: Fakultas Hukum UMY. 
Hadjon, Philipus M, 1984. Perlindungan Hukum Bagi Masyarakat Indonesia, Surabaya : Universitas Airlangga.

Ibrahim, Johnny, 2006. Teori dan Metode Penelitian Hukum Normatif, Malang: Bayu Media.

Kosasih, Ahmad, 2003. HAM dalam Prespektif Islam; Menyingkap Persamaan dan Perbedaan Antara Islam dan Barat, Jakarta: Salemba Diniyah.

Lopa, Baharudin, 1996. Al Quran dan Hak-hak Azasi Manusia, Yogyakarta: PT, Dhana Bakti Prima Yasa.

Manan, Bagir, 2001, Menyongsong Fajar Otonomi Daerah, Yogyakarta: Pusat Studi Hukum FH UII.

Marzuki, Peter Mahmud, 2005. Penelitian Hukum, Jakarta: Prenada Media.

Meuwissen, D.H.M., Ilmu Hukum (Penerjemah B, AriefSidharta), Pro Justitia, Jurnal Unika Parahyangan, Tahun XII No, 4, Oktober 1994.

Munir,1998. Pengorganisasian Buruh Perempuan, Surbaya : LBH.

Paul, Smoke, Eduardo J Gomez, and George E, Peterson eds, Decentralization in Asia and Latin America: Toward Comparative Interdisciplinary Perspective, UK: Edward Elgar Publishing.

Purbopranoto, Kuntjoro, 1982. Hak-hak Asasi Manusia dan Pancasila, Jakarta: Pradya Paramita.

Sarundajang, 1990. Arus Balik Kekuasaan Pusat ke Daerah, Jakarta: Pustaka Sinar Harapan.

Sidharta, B, Arief, 2000, Refleksi tentang Struktur Ilmu Hukum, Sebuah Penelitian tentang Fundasi Kefilsafatan dan Sifat Keilmuan Ilmu Hukum Sebagai Landasan Pengembangan Ilmu Hukum Nasional Indonesia, Bandung: Mandar Maju.

Soekanto, Soerjono, 1986, Pengantar Penelitian Hukum, Jakarta: UI Press.

Syaukani, Afan Ghafar, dan M, Ryaas Rasyid, 2002, Otonomi Daerah dalam Negara Kesatuan, Yogyakarta: Pustaka Pelajar.

Tim Penyusun Kamus, 2002, Kamus Besar Bahasa Indonesia, Jakarta:Balai Pustaka.

Tim Penyusun, 2010, Naskah Komperehensif Perubahan UUD Tahun 1945, Jakarta: Sekjend MKRI.

Turner, M, Podger, O, Sumardjono M, and Tirtayasa, W,K, 2003, Decentralisation in Indonesia: Redesigning the State, Australia: Asia Pacific Press.

Wignyosoebroto, Soetandyo, 2002, Hukum: Paradigma, Metode, dan Dinamika Masalah-nya, Jakarta: Penerbit Huma

, dk, 2005, Pasang Surut Otonomi Daerah Sketsa Perjalanan 100 Tahun, Jakarta: Penerbit Tifa \& Institute for Local Development. 
Zakaria, A, Syamsu, 2004, "Negara Hukum dan Hak Asasi Manusia, Wacana dan Dilema HAM di Indonesia", dalam Bunga Rampai Karya Tulis Alumni Pelatihan HAM Luar Negeri, Jakarta: Ditjen Perlindungan HAM Departemen Hukum Dan HAM RI.

\section{B. Peraturan Perundang-Undangan}

Indonesia,Undang-Undang Dasar Negara Kesatuan Republik Indonesia Tahun 1945.

, Undang-Undang Nomor 32 Tahun 2004 tentang Pemerintahan Daerah, Lembaran Negara Republik Indonesia Tahun 2004 Nomor 125, Tambahan Lembaran Negara Republik Indonesia Nomor 4437, sebagaimana diubah terakhir dengan Undang-undang Nomor 18 Tahun 2008 tentang Perubahan Kedua Atas Undang-undang Nomor 32 Tahun 2004 tentang Pemerintahan Daerah.

, Peraturan Pemerintah Nomor 38 Tahun 2007 tentang Pembagian Urusan Pemerintahan Antara Pemerintah, Pemerintahan Daerah Provinsi, Dan Pemerintahan Daerah Kabupaten/Kota, Lembaran Negara Republik Indonesia Tahun 2007 Nomor 82, Tambahan Lembaran Negara Republik Indonesia Nomor 4737. 